\title{
The Affective Politics of Interfacial News: Danish News Media's Coverage of \#MeToo on Facebook
}

CAMILLA MØHRING REESTORFF

\section{INTRODUCTION ${ }^{1}$}

The \#MeToo movement was iniated by civil rights activist Tarana Burke in 2006 when she began using the hashtag to raise awareness about sexual assault and harassment. Yet, the hashtag and the movement did not go viral until 2017 when actress Allyssa Milano tweeted: "Suggested by a friend: 'If all the women who have been sexually harassed or assaulted wrote "me too," as a status, we might give people a sense of the magnitude of the problem'" (Milano 2017). The hashtag spread rapidly ${ }^{2}$ and covered intensely by mainstream news media. In Denmark alone 3,184 articles about MeToo occurred in nationwide newspapers in the movement's first two years (October 2017-October 2019). This chapter conducts a categorical mapping and study of the coverage of \#MeToo on Facebook by the nine largest Danish news media outlets\#MeToo. Thus, the object of the study is not \#MeToo as a social movement, but the way in which news about \#MeToo is communicated, circulated, and negotiated by news media and news consumers on social media. 
When news media share their articles and write Facebook posts about \#MeToo, they negotiate the event \#MeToo. Brian Massumi associates the event with intensity and suggests that it constitutes "a state of suspense, potentially of disruption. It is like a temporal sink, a hole in time, as we conceive of it and narrativize it" (Massumi 2002, 26). The event, \#MeToo, ruptures the lines of continuity and the institutionalised order through which sexual assault and harassment is usually governed. In this regard \#MeToo exhibits the " absurdity of significations" and it is "never present, but always already in the past and yet to come" (Deleuze 1994, 136). However, \#MeToo is not only qualifiable as an event; it is also negotiated in a number of specific occurrences. One of these occurrences is the media coverage of \#MeToo on Facebook in Denmark, studied in this chapter. By focusing on this occurrence it is not only possible to understand how news media attempt to narrativize and govern the event, but also how news is transformed when communicated on Facebook. In this chapter it is, thus, studied how news and the relationship between news and news consumers are transformed and manifested in what I will refer to as an affective politics of interfacial news.

In order to understand how this transformation comes about and how it impacts the news coverage of \#MeToo, I first conduct a categorical mapping of an archive of Facebook posts about \#MeToo in news media. Then, this I proceed to consider how news, when shared on Facebook, is impacted by both ordinary affects and a surveillance capitalist logic of accumulation. Third, I study news consumers' Facebook comments and suggest that the angry refrains that these comments exhibit, circulate and intensify in-between news media, social media, and news consumers. Finally, I argue that while transformations of news to some extent can be explained by the affordances of social media and the impact of surveillance capitalism, this does not fully explain the predominantly negatively framed articles and Facebook posts about \#MeToo. Rather, these suggest an affective politics of interfacial news that pertains to a specific politics concerning sexual harassment and abuse; a policy that foregrounds the emotionality of news consumers, intensifies angry refrains directed towards \#MeToo, and has consequences for the victims of sexual assault and harassment's ability to access the public debate. 


\section{METHOD AND INITIAL RESULTS}

In this chapter I map and investigate news about \#MeToo shared on Facebook by the nine major Danish news media (the two public service channels: DR, TV2, and the seven newspapers: Politiken, Berlingske Tidende, Information, Jyllands-Posten, Kristelig Dagblad, Ekstrabladet, and B.T.) in the the coverage of the movement's first year (October 1, 2017 to November 1, 2018). The focus on news media's communication on Facebook was chosen, because Facebook in Denmark, is the most frequently used social media site both amongst the population, politicians, and news media (Slots og Kulturstyrelsen 2019).

Each Facebook-post (FB-post) included in the study contains the hashtag \#MeToo. Had more than one keyword been included in the search then there would, most likely, have been more articles related to sexual assaults and harassment. Yet, by limiting the search to one keyword it was possible to study the ways in which sexual harassment and assault was covered, not in general terms, but specifically in relation to the \#MeToo movement.

In order to study the coverage of the \#MeToo movement, the methodology of categorical mapping (Fritch, Kofoed \& Reestorff 2020) was applied. Categorical mapping is inspired by Adele Clarke's methodology of mapping and her work on situational analysis (Clarke 2005). However, in this study the focus is not on situational maps but on laying out visually what is in the archive by categorizing the ways in which \#MeToo is being addressed (Fritsch, Kofoed \& Reestorff 2020). In this regard, categorical mapping approaches an archive (Rasmussen 2020) - in this case FB-posts about \#MeToo- and reorganizes it according to main categories, thus rendering it possible to grasp what is already in the archive. For instance, by mapping positive and negative attitudes towards \#MeToo the complexity of the reception becomes visible and the otherwise intangible \#MeToo-stream becomes real.

In the period of time studied, 371 of the news media's FB-posts were tagged with \#MeToo on Facebook. By further mapping these it becomes apparent that $138 \mathrm{FB}$-posts concern the media and entertainment industry (e.g. \#metoo, \#MeToo in Hollywood), 74 are opinion articles, 104 present a negative framing, and 66 a positive framing of \#MeToo. In the following table the FB-posts and the mapping are outlined. 
Figure 1. Categorical mapping of the 371 Facebook-posts tagged with \#MeToo

\begin{tabular}{l|l|l|l|l|l} 
NEWS MEDIA & $\begin{array}{l}\text { ABOUT } \\
\text { \#METOO }\end{array}$ & $\begin{array}{l}\text { \#METOO IN MEDIA/ } \\
\text { ENTERTAINMENT } \\
\text { INDUSTRY }\end{array}$ & $\begin{array}{l}\text { POSITIVE } \\
\text { FRAMING }\end{array}$ & $\begin{array}{l}\text { NEGATIVE } \\
\text { FRAMING }\end{array}$ & $\begin{array}{l}\text { SHARING } \\
\text { OPINION } \\
\text { PIECES }\end{array}$ \\
\hline B.T. & 24 & 13 & 2 & 9 & \\
\hline Berlingske Tidende & 65 & 20 & 9 & 23 & 16 \\
\hline Dagbladet Information & 63 & 12 & 17 & 14 & 13 \\
\hline Dr.dk \& DR Nyheder & 48 & 24 & 5 & 13 & \\
\hline Ekstrabladet & 11 & 6 & & 5 & \\
\hline Jyllands-Posten & 44 & 18 & 5 & 16 & 10 \\
\hline Kristelig Dagblad & 9 & 2 & 1 & 2 & 4 \\
\hline Politiken & 70 & 17 & 24 & 15 & 31 \\
\hline TV2 \& TV2 News & 37 & 26 & 3 & 7 &
\end{tabular}

In this context positively and negatively framed FB-posts refer to updates and articles in which the journalist, the news media, or the opinion writer reveal an explicit opinion on \#MeToo, or in which the post and the article are exclusively framed around a person that holds a positive or negative attitude towards \#MeToo. An understanding of framing is useful in order to highlight how news, "not only report[s] about reality but contains a number of structural choices that ascribe meaning to events and reflects different players interests" (Hjarvard 2015). This suggests that by communicating, news frames will be selected and thus some elements will be foregrounded and others left out. Furthermore, frames often both define a problem and suggests a moral interpretation of the cause of the problem (Entman 1993). Such frames are, for instance, evident when Jyllands-Posten posts the article, "Comment: Perhaps it is about time that the \#MeToo movement lie down to die" (Jyllands-Posten 2018). Then the comments on the article in their accompanying Facebook post by quoting a historian, Henrik Jensen, saying, "“\#MeToo appears to have reached a point where the movement radicalizes to an unfolded gender war or lie down to die"(Jyllands-Posten 2018). They then invite response by asking "What do you think-is it time to bury the metoo-movement?" In mapping a FB-post such as this, it is categorized as an example of a negative framing of \#MeToo. This is because the headline and the accompa- 
nying Facebook post mention 'radicalized gender-war' and suggest three times that \#MeToo ought to die. Furthermore, the article and the update are exclusively framed around a person who is highly critical of \#MeToo. By suggesting FB-posts can be mapped according to their framing of news stories it is, thus, acknowledging that to tell and report a story is never completely neutral but requires a continuous evaluation of which stories and whose voices are attributed the dominant position (Wänggren 2016). Accordingly, categorical mapping can contribute to identifying patterns in the archive, e.g., which voices are prioritized and attributed the dominant position. Nevertheless, a further analysis is required to understand why these patterns emerge and what their consequences might be.

At least four analytical points can be drawn from the categorical mapping. First, in the 371 FB-posts only two Danish men are named; these two are Peter Aalbæk Jensen and Lars von Trier. They are both from Zentropa Film and particularly Aalbæk Jensen's problematic behavior toward interns, plus Lars von Triers controversies with Björk have been public knowledge for at least ten years-thus prior to \#MeToo ${ }^{3}$. Despite the fact that only these two men are named in the Facebook posts and articles, concerns about the harm \#MeToo might cause men is repeatedly emphasized. These potential problems are repeatedly "premediated" (Grusin 2010). It is, for instance, often raised as a concern that innocent men risk being named and shamed. An example of this kind, of premeditation, occurred when newspaper Jyllands-Posten posted an editorial with the headline "JP believes: The \#MeToo movement will end in \#youtoo and free access to naming and shaming" (Jyllands-Posten 2017). The headline was accompanied by the post: "There is no doubt that \#MeToo has provided the silent with a voice and that there is something worth looking at. But the movement can get out of hand and bring innocents down" (Jyllands-Posten 2017). However, in a Danish context it is crucial to keep in mind that accounts of sexual assault and harassment rarely name and shame the alleged assailants.

Second, the categorical mapping also reveals that \#MeToo is often covered as Hollywood and gossip journalism, i.e., the kind of "personality journalism" typified by the concentration on the private life of individuals, specifically in terms of scandal and entertainment (Petersen 2011). Thus, when 138 Facebook posts focus on the media and entertainment industry - for instance in Facebook posts about allegations against Kevin Spacey or about Danish comedians saying \#hetoo-the coverage utilizes a 
strong tradition, from personality journalism namely, to combine celebrity and human-interests stories. This kind of personality journalism is not only posted by the tabloids. Politiken, for instance, often emphasizes that they are printed in broadsheet and that this, "marks that we are something special. The differentiation argument is really something, which has value to us" (Madsen 2008, n.p.). ${ }^{4}$ Yet, while they might be printed in a broadsheet, Politiken's FB-posts also draws on the logics of personality journalism. In a FB-post for instance they share the article, "\#MeToo-men are making a comeback: Are you ready to forgive Louis C.K., Kevin Spacey, and James Franko?" (Politiken 2018).

Third, the point rendered evident by the categorical mapping is that nearly $20 \%$ of the Facebook posts link to opinion pieces about \#MeToo. In line with the focus on personality journalism, the opinion pieces suggest that \#MeToo is something everybody is entitled to have an opinion about, and not as something that necessarily demands in-depth journalism or political attention and action. Personality and opinion journalism is in itself not problematic. On the contrary, it is "a lucrative industry in its own right" and "mass-mediated gossip has helped to shape and reflect personal, group, and national identity and reinforce and challenge social norms and ideals" (Feeley 2012, 475). In this regard, gossip and opinion journalism offers insight into contemporary attitudes and debates and, thus, also into the values that are negotiated in relation to movements such as \#MeToo. Yet, at the same time, the emphasis on gossip and opinion journalism is problematic because it rarely concerns the fundamental challenges raised by \#MeToo, and because the articles that do in fact discuss sexual assaults and \#MeToo as a challenge, tend to get drowned out in the large amount of gossip and opinion journalism.

Finally, this leads to the categorical mapping's fourth point, namely that seven out of the nine media outlets have more than twice as many negatively framed FB-posts about \#MeToo than positively framed posts. Thus, there is a significant negative distortion of the coverage of \#MeToo on Facebook. The negative distortion correlates with the voices that are attributed the dominant position in the FB-posts. In this regard it is interesting that there is a tendency to name male journalists, opinion writers, and scholars in the posts. For instance, Politiken writes, "the master thinker Fukuyama," and Berlingske Tidende mentions the names of six of their opinion writes in their FB-posts and only one of whom is female. ${ }^{5}$ Furthermore, there is a tendency to promote women who are critical 
of \#MeToo in the FB-posts. Politiken, for instance, has seven FB-posts centered around Marianne Stidsen, associate professor at the University of Copenhagen, who amongst other things claims that the \#MeToo movement is a "feminist, left-populist totalitarianism comparable to the wildfires that have been spreading across the country all summer" (Stidsen in Politiken 2018c). BT quotes former porn star Sussi la Cour for questioning the \#MeToo movement and asking: "Where are the womens' self-respect in regards to saying no?" (la Cour in BT 2018). This suggests that not only is the framing of \#MeToo predominantly negative in the FB-posts, \#MeToo is also positioned as a "form of problematic 'willfulness'" (Mendes, Ringrose, \& Keller 2019, 25). On the one hand women lack 'self respect' if they do not speak out, but on the other hand if they do speak out they are aligned with, for instance, 'totalitarianism' (in FB-posts by Politiken) and 'gestapo' and 'reactionary witchhunt' (in FB-posts by Berlingske Tidende). This renders it evident that it is necessary to study the ways in which news and the relationship between news media and news consumers are transformed on social media.

\section{THE AFFECTIVE POLITICS OF ORDINARY AFFECTS}

In 2017 the report, "The Media's Development in Denmark" (Slots og Kulturstyrelsen 2017) suggested that the Danish media industry, since the turn of the century, has become fundamentally affected by and dependent on companies such as Facebook, Google, Netflix, and Apple, and that these companies increasingly dictate both the technological infrastructure, the commercial standards, and the market conditions in which Danish media must navigate. These news infrastructures also contribute to a transformation of news and of the relationship between news media and news consumers. For instance, news is increasingly-especially by the younger generation-accessed via social media (Danmarks Statistik 2019). This has created a particular type of "social news" (Hermida 2012), which entails that news consumers access news through their social media feeds and via friends' and family's likes and shares. Social news relies on the altered infrastructures of news, and they broaden the field of journalism by including a wide range of both professional and citizen journalism, and by broadening the understanding of what constitute news (Hermida 2012). However, social news does not imply that professional news media 
has lost importance. On the contrary, news shared on social media are often produced by professional media and shared either by themselves or their followers.

Social news alters the affective politics of news. As I have argued elsewhere (Reestorff 2017), affective politics is a political practice that is played out by different political participants within a mediatized political arena. By drawing on symbolic media representations as well as affective repetitions and intersections in the national symbolic, affective politics seeks to govern the relationship between the individual life of human beings and different forms of collective communities (Reestorff 2017, 18). By considering news as partaking in such affective politics, I understand journalism as relying upon both strategic rituals of objectivity and emotionality (Wahl-Jorgensen 2019). These rituals, I argue, contribute to creating relations between news media, their followers, and different kinds of collective communities. In this regard, what I will term the affective politics of news, relies upon news medias' ability to allow their followers to become "whole by being reconstituted as a collective subject or citizen" (Berlant 1991, 24, original emphasis).

Furthermore, the affective politics of news is altered when news is communicated on social media. One of the reasons why this is the case is that news on social media is shaped by the "ordinary affects" of everydayness and thus by a type of affect that is registered in its particularities, while simultaneously connecting people, creating common experiences, and thus shaping public feeling (Stewart 2017). When you, for instance, access news via a friend on Facebook you might do so because you share values with the person who shares the news. This recommendation logic alters the affective politics of news, simply because news becomes legitimized, not only by professional news media, but by also by the friends who share it.

The alteration of the affective politics of news does, however, not only pertain to news media's utilization of Facebook as an infrastructure for communication, but also to the ways in which specific modes of "storytelling structures of feelings" (Papacharissi 2016) are applied. Thus, when news media renders use of personality journalism or, for instance, includes celebrity bloggers and commentators, they (potentially) activate storytell- 
ing structures of feeling because they tap into ordinary affects and provide the illusion that news is written or recommended by someone you know (or think you know).

\section{THE AFFECTIVE POLITICS OF INTERFACIAL NEWS}

As mentioned above journalism has, at least in a Danish context, been altered by companies such as Facebook, Google, Netflix, and Apple, and the media infrastructures that they provide. This entails a challenge to the fundamental business model of journalism because it renders "what is good for the audience-more news from more sources in more ways" at odds with "the financial health of the news industry" (Rasmus Kleis Nielsen in Witschghe et al. 2016, 6). This challenge must of course be taken into account when considering the ways in which news about \#MeToo is communicated on social media.

The challenges faced by news media entails that they are reinventing themselves, to attract an audience that - due to the new social media infrastructures - can access news both off- and online and via multiple interfaces and news outlets (Sheller 2015). In this media environment a range of interfaces provide a relation between news consumers and the information they seek, from print media to news apps, blogs, and podcasts. These interfaces are not just specific technologies, they are symbolic systems that "filter information and actively reshape communication relationships, and also reshape the space in which social interaction takes place" (de Souza e Silva \& Frith 2012, 4). Thus, when news is shared and spread through multiple interfaces it reshapes the spaces and ways in which interaction about \#MeToo takes place.

The affective politics of interfacial news are, as mentioned above, altered by social media and the ordinary affects associated with accessing news via the feeds of family and friends. Yet, when news media post updates on social media they also appear to attempt to cue heightened emotionality. Consider for instance the article, "Bertel Haarder famous Danish politician interferes in the \#metoo-debate as an old 68er," accompanied by the update: "It is too bad if we end up being as sex-fixated and squeamish about bodies as some Muslim environments, for instance, are" (Jyllands-Posten 2017b). The phrasings "sex-fixated," "squeamish about bodies," and "some Muslim environments" suggest that there is a 'we' among the readers who do not want to be as sex-fixated and squeamish as 
'they' are. In the archive studied, news media often either use a provocative quote from a source, make an emotional framing of the story, and/or ask their followers open-ended questions. This indicates that news about \#MeToo, when communicated on social media interfaces, renders use of a "storytelling structures of feelings" ) that invoke both ordinary affects and heightened intensity.

The affective politics of interfacial news certainly concerns intensity. In fact, social media analytics "measure 'social velocity' to understand the intensity of news sharing (and other social signals) as a measure of information relevance" (Martin \& Dwyer 2019, 32). Yet, the desire for intensity does not necessitate a specific framing of news. Kasper Welbers and Michaël Opgenhaffen (2018) have argued that subjectivity is a core element of news on social media and that news media simply try to adapt to the social media platforms on which news is shared. This includes, "the subjective elements that characterize communication on social network sites, in order to fit in and improve the reach and virality of their news content" (Welbers \& Opgenhaffen 2018, 49). Furthermore, in the context of news on Twitter, emotionally charged tweets, "tend to be retweeted more often and more quickly compared to neutral ones" (Stieglitz \& DangXSuan 2013, 217).

However, the fact that subjectivity is a core element of news on social media does not necessarily explain the predominance of FB-posts that frame \#MeToo in a negative manner. Further, if the aim is to increase engagement and intensity the fact that the majority of posts hold a negative attitude towards \#MeToo is not necessarily beneficial. On the one hand it can be argued that, "if you want to be cited: Sweet talk your friends or serve bad news to the public!" (Hansen et al 2011, 34). Yet, on the other hand Ahmed Al-Rawi suggests that social media news readers prefer to read and share positive news, and that "social significance and unexpectedness in news stories are the most appealing viral news elements" (Al-Rawi 2017, 63). Likewise, Welbers \& Opgenhaffen (2018) found that news media's "status messages contain more positive language compared to headlines and leads" and argue that this confirms "a shift towards a more subjective and positive style of communication of journalists on social media" (57-58). This entails that the transformation of affective politics of the news - in relation to the coverage of \#MeToo-not only pertains to the interfacial news and the affective "platform vernaculars" 
(Gibbs et al. 2015). Rather, certain topics - including \#MeToo-break with the tendency towards a positive style of news communication on social media.

Brian Massumi argues that affect concerns microshocks, "for example a change in focus, or a rustle at the periphery of vision that draws the gaze toward it. In every shift of attention, there is an interruption, a momentary cut in the mode of onward deployment of life" (Massumi 2009, 4). This concept of affect may help us understand the dynamics of the \#MeToonews. If the affective 'platform vernaculars' (Gibbs et al. 2015) affords a positive style of news communication, then the predominant negative framing of FB-posts about \#MeToo suggest a microshock, an interruption of the otherwise positive style of communication. This interruption cannot simply be explained by interfacial news, but must pertain to an affective politics that relates to the topic covered, namely sexual harassment and abuse.

\section{NEWSWORTHY SURVEILLANCE CAPITALISM}

The coverage of \#MeToo on Facebook is shaped by the affective politics of interfacial news as well as an affective politics that pertains to a specific politics concerning sexual harassment and abuse. Furthermore, the coverage of \#MeToo is shaped by the logics of communicative capitalism, i.e., "the form of late capitalism in which values heralded as central to democracy materialize in networked communications technologies" (Dean 2014, 4). According to Jodi Dean, contemporary protest movements are the first phase of the revolt of the knowledge class (Dean 2014, 1). This might also be the case in relation to \#MeToo. Nevertheless, the attempt to gain visibility through the number of shared tweets and posts borrows from the logics of communicative capitalism. \#MeToo's idea is simply that numbers - retweets, shares, and posts that can be counted-can convince people that sexual harassment and assault exist and need to be dealt with. This mimics communicative capitalism because it indicates that it does not matter what kind of stories people tell-it matters that they can be counted.

Communicative capitalism is crucial not only to understand how \#MeToo is spread, but also how news media utilize social media in the coverage of \#MeToo. This is not only because communicative capitalism, as shown above, alters the ways in which news media communicate, but 
also because communicative capitalism changes to whom news communicates with and why. News obviously communicates to news consumers, but they also communicate, for instance, to their advertisers. This double communication is, for instance, evident in the questions news media ask their followers. The posts are often followed by the questions, "do you agree?" and "what do you think?" A number of Facebook posts position a person as someone you are invited to either agree or disagree with. These following two examples are from the tabloid B.T. and the public service media $D R$ :

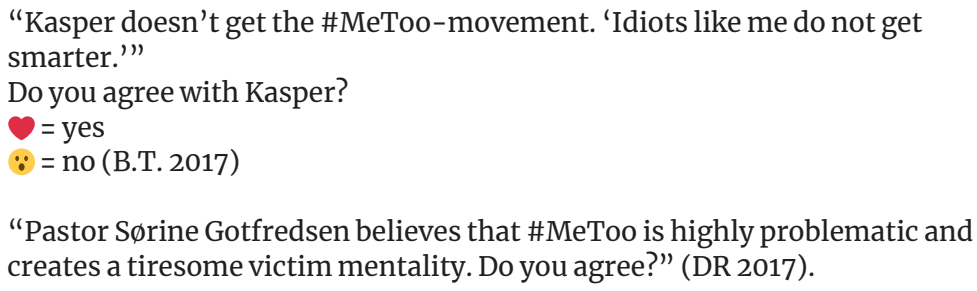

"Pastor Sørine Gotfredsen believes that \#MeToo is highly problematic and creates a tiresome victim mentality. Do you agree?" (DR 2017).

The purpose of asking these kinds of open-ended questions, in which your option is either to agree or disagree, and in which your position can simply be marked by an emoji, is to gain likes, shares, and comments that can be measured and counted. In this regard it does not matter what the users write in the comment field; it only matters to the news media that their content is shared on social media, that readers like, share, and comment in a manner that can be counted. As such, news is transformed from the primacy of messages as communication to "the primacy of its exchange value, to its capacity to circulate, to be forwarded and to be counted" (Dean 2004, 6). News media are often financially dependent on the exchange value, ${ }^{6}$ not only of their news, but on the "spreadability" (Jenkins, Ford \& Green 2013) that occurs when users comment, like, and share news. This implies that to some extent the value of communicating or interacting with followers on social media is neither aiming to inform nor educate the public but to utilize the public as a commercial exchange value.

Shoshana Zuboff suggests that we need to consider big data - such as the data gathered when users comment on news media's Facebook-not just as data or as a consequence of certain algorithms but as "deeply intentional and highly consequential new logic of accumulation" (Zuboff 2015, 75). This understanding of surveillance capitalism suggests a transformation of both the ways in which social movements are spread and the ways in which news media function. The logic of accumulation renders both 
journalism and everyday engagement with news content on social media as part of a "shift that makes everydayness qua data imprints an intrinsic component of organizational and institutional life" and "a primary target of commercialization strategies" (Constantiou \& Kallinikos 2014, 10). These strategies depend on making people engage with news.

When news media, for instance, ask open-ended questions to enhance to probability of user engagement, intensity, and spreadability, the goal is not only for the content to be spread; it is also laying claims to users' "private experience for translation into fungible commodities that are rapidly swept up into the exhilarating life of the market" (Zuboff 2019, 10). This furthermore suggests that news becomes embedded in the circulation of predictions products. When readers and users are no longer ends-in-themselves they become, "means to profit in new behavioral futures markets in which users are neither buyers nor sellers nor products" (Zuboff 2019, 13). Instead followers and their interaction with news content are "free raw material that feeds a new kind of manufacturing process designed to fabricate prediction products" (Zuboff 2019, 13). These prediction products can of course be more news that tap into the kind of content proved to be spreadable, but might also be predictions products generated by the companies, organizations, and institutions that profit from the interaction.

\section{ANGRY REFRAINS}

In the example above, pastor Sørine Gotfredsen is quoted as blaming \#MeToo for generating what she refers to as a "victim mentality." In the archive studied, "victim mentality" is a reoccurring refrain. Refrains can, following Deleuze and Guattari, be understood as:

a prism, a crystal of space-time. It acts upon that which surrounds it, sound or light, extracting from it various vibrations, or decompositions, projections, or transformations. The refrain also has a catalytic function: not only to increase the speed of the exchanges and reactions in that what surrounds it, but also to assure indirect interactions between elements devoid of so-called natural affinity and thereby to form organized masses (Deleuze \& Guattari 1987, 119).

Refrains form masses from that which moves, and may even appear at odds. Lone Bertelsen and Andrew Murphie (2011) explain that a focus on refrains orients the analysis towards understanding the role of the refrain in the emergence of new territories, new functions within this territory, 
and the further refraining of this new territory and new functions. A focus on refrains is thus not only a way to focus on words and language, but a way of understanding how afective mobilization and political territories are attached to words (Fritsch, Kofoed \& Reestorf 2020).

In order to understand how the affective politics of interfacial news and the prediction logic of surveillance capitalism impact the ways in which users engage with news content about \#MeToo it is necessary to understand how refrains are circulated and how they stick to \#MeToo. The 329 comments below the TV2's FB-post sharing the above-mentioned article, "Famous Danes warn about frenzy of bloodlust: is this the kind of society we want?" are often negative toward \#MeToo. Comments, for instance, claim that \#MeToo is an "unreasonable witchhunt," that "unless you report it to the police, you must let it go," and that "women must take responsibility for their own actions," or that "everyone is now free to burn whomever they don't like" (TV2 2017). Many of the comments are clearly attuned to the framing and alertness suggested by the words "frenzy of bloodlust." Interestingly, however, similar refrains occur in relation to FB-posts that are neutrally framed.

$D R$ 's neutrally framed FB-post about the article "\#MeToo continues in Denmark: 132 female singers call for action" (DR 2017b) reports that female classical singers demand a better working environment in the music industry. It does not name any accused. In the comment field on Facebook there are 168 comments. It has thus been less commented upon and shared than the article from TV2. Yet, despite the neutral framing, 101 comments attack \#MeToo, 59 comments find \#MeToo necessary, and 8 comments are impossible to understand or attack others in the thread.

In the comment field at least fifteen refrains reoccur and act as catalysts for anger towards \#MeToo. These refrains are:

- Time (e.g. allegations "must be made immediately")

- Fame (e.g. women saying \#MeToo are "in it for the fame")

- Pathetic (e.g. \#MeToo is "unnecessary whining")

- Violation culture (e.g. \#MeToo is "oversensitive")

- Undocumented claims (e.g. \#MeToo accounts are "not documented")

- Smack in the bum (e.g. \#MeToo "does not concern real abuse")

- People's court (e.g. \#MeToo is "disregarding justice")

- Real victims versus victim mentality (e.g. \#MeToo does not concern "real abuse")

- Female sounds (i.e. "whining" or "howling")

- Quit (e.g. if abused you can simply "quit your job") 
- Extreme \#MeToo (e.g. \#MeToo is "bloodlust," "tsunami," or "tidal wave")

- Witch hunt (e.g. \#MeToo is "hunting innocent men")

- Anti-feminism (e.g. anti-Kvinfo [knowledge center about gender, equality and ethnicity])

- Media frenzy (e.g. \#media are "bursting into self-oscillation")

- The loss of flirtation (e.g. men will "loose their initiative")

As these refrains indicate, the neutral framing found in DR's FB-post is not mimicked in the comment field. Rather, the comment field appears to gain its intensity from refrains found in other news - including the article from TV2. Furthermore, many of the refrains have already been introduced in other news stories. Berlingske Tidende, for instance, shared an article titled: "Men reply to \#MeToo: 'it is a reactionary witchhunt") and DR shared "We need to talk about a triviality limit, argues Hans Bonde, about the violation culture in relation to \#MeToo" (DR 2017c). Words and phrases such as witch hunt and violation culture are thus already introduced and framed as everyday language in the news media themselves. Thus, while it can be difficult to determine whether or not news media's negative framing of \#MeToo impacts the users' attitude towards \#MeToo, media texts often attach themselves to informal speech even though these words and phrases are only common in the informal speech because they were introduced by the media texts in the first place (Warner 2007).

The reoccurring use of refrains in the comments intensifies an affect intensive atmosphere. Without distinguishing between affects and emotions, Sara Ahmed writes that emotions "are intentional in the sense that they are 'about' something: they involve a direction or orientation towards an object" (Ahmed 2004, 7). In the comments field, angry affects are certainly oriented toward \#MeToo, but also toward women more generally, the media, feminism, and the unidentifed and allegedly innocent men. Furthermore, affects become "sticky" (Ahmed 2004) when refrains such as "witch hunt" and "smack on the bum" are repeated. The refrains provide the affective cues and orientations that allow the users in the comment field to emerge as an angry public. In the context of Twitter, Zizi Papacharissi argues that tweets work as framing devices that allow publics to emerge because they provide a way in which people can "feel their way in to politics," and thus "tune into an issue or a particular problem of the times, but also to affectively attune with it" (Papacharissi 2015, 118). In a similar manner the users in the comments field feel their way into the politics of \#MeToo. However, they are not necessarily 'in tune' with 
\#MeToo; their affects are not oriented towards \#MeToo but towards the angry refrains that are sticking to it. This also entails that the comment feld is not only about \#MeToo, but also about the affective intensification itself. For example, when a user is the twentieth to write "witch hunt" that person is not contributing to a dialogue, but merely adding affect to the collective intensification.

Furthermore, the angry refrains suggest that a specific form of affective "platform vernacular" (Gibbs et al. 2015) emerges in and around comments fields related to \#MeToo. Katie Warfield (2016) has argued that while platforms such as Facebook certainly impact the way in which we communicate, platform vernaculars also emerge from within social networks and through the continuous engagement of its users. In comments fields attached to news media's posts the vernacular is shaped not only by the affordances of social media, but also by the news media's social media presence. In this regard, the affective politics of interfacial news also impacts the platform vernacular of social media. When news media breaks with their otherwise subjective and positive style of communication on social media and consistently frames news about \#MeToo in a negative manner -i.e. by utilizing refrains such as "witch hunt" or "victim mentality" - they contribute to the enhancement of angry refrains as key elements in the platform vernaculars surrounding \#MeToo.

The fact that angry refrains circulate between news media and media consumers is crucial because it allows us to understand a key element about anger online. When people are angry online it is often described as an individual problem or disregarded as, for instance, trolling. Yet, the angry refrains and the intensity that sticks is passing between news media, social media, and news consumers, and cannot be reduced to any one of them. As we recall, the refrains found in the comments field can also be found in the archive, for instance, in articles such as, "Movie Director Ole Bornedal argues that it is difficult not to laugh when women feel traumatized 25 years after a smack on the bum" (Politiken 2017). In fact, all the news media have posts and articles that mention either witch hunt, people's court, or warns that we must not feel violated too easily. Thus, angry refrains appear to be legitimized in the news media's articles and FB-posts and, as such, the intensity of the angry refrains are ingrained as part of the affective politics of interfacial news in relation to \#MeToo. 


\section{GOVERNING WHAT CAN BE FELT}

As discussed above, the affective politics of interfacial news make use of and legitimize angry affects. Furthermore, they contribute to a specific governmentalization of \#MeToo and accounts of sexual assault and harassment. The emphasis on "what can be counted" contributes to a shift in emotionality in news communication. As mentioned above, journalism draws on both a ritual of objectivity and a ritual of emotionality (Wahl-Jorgensen 2019). However, when news is communicated on Facebook the ritual of emotionality is prioritized. Furthermore, it is not only the emotionality of news that is prioritized, but also the emotionality of the consumer. In many of the posts, emotionality is put in the hands of the news consumers (e.g. when they are being asked what they think). But emotionality is also frequently premediated and oriented toward possible future false accusations (of men) (Grusin 2010)

In this regard, news consumers are asked to validate truth claims that the news media themselves, or their sources, put forward. For instance, an article shared by $D R$ reports that the Swedish Press Council has criticized some articles about \#MeToo, and DR asks their followers, "do you agree with them?" (DR 2018). As if Danish news consumers (pay to) read Swedish journalism or have knowledge about press ethics. This is as mentioned a way to enhance and predict comments that can be counted, but it also suggests that the affective politics of interfacial news alters the logics of emotionality in news communication exactly because the truth-claims of news is placed in the hands of the news consumers. ${ }^{7}$

The affective politics of interfacial news thus often shifts the ritual of emotionality from the sources of the news stories to the news consumers, who are asked not only to feel their way into the refrains sticking to \#MeToo, but also to judge the truth-value of the news shared by the media themselves. Thus, news media simultaneously assert their power through the predominantly negative framing of \#MeToo and circulation of angry refrains, and suggest that news consumers are free to judge every claim put forward. Yet, this freedom is obviously shaped by the platform vernacularism, which as we recall is shaped not only by news consumers, but also news and social media.

The shift in emotionality in news shared on social media does not only alter news media and the relationship between news media and news consumers. It also has consequences for victims of sexual assault and 
harassment who might come forward. When news consumers are invited to be the judge of the truth value of news, they also become the judge of what constitutes sexual assault and harassment. This means that the boundaries for what constitutes an assault are up for negotiation in media and public debate, and constantly shift according to where emotionality is placed and where the affective relations occur. This means that victims may come forward-for instance, to the police or the media-but they never know whether or not their testimony will be heard and listened to, and if they will be accepted as victims of assault, precisely because what constitutes assault is shifting.

The fact that emotionality is placed in the hands of news consumers means that victims' experiences with sexual assault and harassment are negotiated in the context of news consumers' emotionality. This is for instance evident in the comment fields below "\#MeToo continues in Denmark: 132 female singers call for action." One FB-user, for instance, comments that he has the ability and right to dismiss the singers' experiences and states that, "I can distinguish between assault, real violations, and self-absorbed nonsense. As long as violence is not involved, we often decided if we let it happen." Likewise, the movie director Christian Braad Thomsen argues to TV2 that "The \#MeToo-campaign has degenerated into a media stunt with no content by covering everything from consummated rapes to sexual jokes" (Braad Thomsen in TV2 2017). In the angry refrains it is thus evident that emotionality is displaced and that in this process the refrain 'real victim' is constantly displaced. Accordingly, it becomes difficult for victims of sexual assault and harassment to be acknowledged as victims, simply because the understanding of what a victim is is constantly shifting. This, again, suggests that the affective politics of interfacial news, social media, and news consumers are closely intertwined through the repetitiveness of angry refrains and, thus, that it is in this muddy intersection where what can be felt is and how affect can be directed in relation to the \#MeToo movement is governed.

\section{CONCLUDING REMARKS}

Throughout this article it has been argued that the media coverage of \#MeToo on Facebook exemplifies a transformation of journalism. On the one hand the media coverage of \#MeToo draws upon both an affective politics of ordinary affects and on the logics of communicative surveillance 
capitalism that dictates data that can be counted. In this regard it does not necessarily matter what the news consumers write; it simply matters that they comment. As such, news consumers are no longer ends-in-themselves, but means to profit in new behavioral futures markets (Zuboff $2019,13)$. These prediction products benefit companies, organizations, and institutions, but they also benefit the news media, who can produce similar articles, i.e., a kind of articles that have proven to be spreadable.

The affective politics of interfacial news engages in surveillance capitalism by producing articles that are spreadable. Yet, the 371 articles and Facebook posts that I have studied are not only spreadable they are also framed in a particular negative manner. This is crucial because research shows that news media most often use a subjective and positive tone on social media, and that social media news consumers prefer to read and share positive news. Thus, the negative framing of posts and articles about \#MeToo cannot simply be explained by their embeddedness in communicative surveillance capitalism. The negative framing also reveals that the news media engages in a specific affective politics and the governing affective attitudes towards the intensities around \#MeToo. In the Facebook posts and articles, angry refrains appear to be legitimized and thus become an acceptable part of the platform vernacular. In the 371 posts and articles and in the comments fields to the article, "\#MeToo continues in Denmark: 132 female singers call for action," a number of angry refrains are repeated. Here it becomes apparent that angry refrains are not merely a product of news consumers' online behaviour, but of a particular relationship between news media, social media, and news consumers and in which the angry refrains are intensified.

Angry refrains that, for instance, suggest that \#MeToo is merely a matter of a "smack on the bum" or is a "witch hunt" depoliticize the movement by removing \#MeToo as a political phenomenon "from comprehension of its historical emergence and from a recognition of the powers that produce and contour it" (Brown 2006, 15, original emphasis). Yet, the affective politics of interfacial news and the angry refrains also further transforms journalism. This is because, when news is communicated on Facebook the emotionality of the news media consumers are foregrounded. This is, however, a paradoxical emotionality because news media simultaneously assert their power through the predominantly negative framing of \#MeToo and circulation of angry refrains, and suggest that news consumers validate the truth-claim of the news communicated. The emotional- 
ity foregrounded is thus embedded in the affective politics of interfacial news and it is shaped by the platform vernarcularism, which, as we recall, is shaped not only by news consumers, but also news and social media.

In the final analysis, the affective politics of interfacial news is shaped by communicative surveillance capitalism. Yet, the news coverage of \#MeToo also reveals an affective politics that moves beyond communicative surveillance capitalism; namely as specific affective politics regarding sexual assault and harassment. This affective politics has consequences for victims. When angry refrains are reproduced and circulated, and news consumers are invited to be the judge of the truth value of both news and accounts of sexual assault and harassment, the boundaries for what constitutes an assault are constantly shifting according to where emotionality is placed and where the affective relations occur. This renders it difficult for victims of sexual assault and harassment to be acknowledged as such, simply because the refrain 'real victim' is a moving target.

\section{NOTES}

1. This chapter builds on the data and develops the analytic points from two earlier pieces (Reestorff 2019a and Reestorff 2019b).

2. Within the first 24 hours Milano's tweet had been tweeted nearly half a million times (Jarvey 2017). In the same timespan there were more than 12 million retweets, comments and reactions to \#metoo on Facebook (CBS 2017) and in March 2018 \#metoo had been widely used in 85 countries (Mahdavi 2018).

3. Bog om Zentropa.

4. All translations from Danish are the author's own.

5. The six names mentioned are Anders Fogh Jensen, Søren Hviid, Morten Sabro, Christopher Ryan, Kaspar Kolling Nielsen, and Anna Sophia Hermansen.

6. In the Danish context that I am studying it is worth mentioning that DR does not run ads because it is a public service media. The remaining eight media all receive state funded media support, yet they are allowed to advertize. However, even though DR cannot advertize they are-as the other news media-molded by surveillance capitalism. One of the requirements for state-funded media support is namely that the media can document that they "appeal to a broad range of users and not alone are targeting specific businesses and professions, members of employers, employees or trade associations, political parties or employees in public institutions ect." (Lov om mediestøtte 2017). While this kind of legislation is certainly not the same as the financial capitalization of users' search actions it is subject to communica- 
tive capitalism's logic of counting. Users' engagement with news is simply a way in which the media can document that they appeal to a broad range of users and thus secure funding.

7. In a context of NGO work Chouliaraki (2013) has argued that a shift in emotionality has occurred that involves a "move from an emphasis on suffering as external reality, to suffering as subjective knowledge, validated by psychological grounded criteria of authenticity" (Chouliaraki 173).

\section{REFERENCES}

Adler, B. (2013). Streams of Consciousness. [online] Columbia Journalism Review. Available at: http://www.cjr.org/cover_story/steams_of_ consciousness.php?page=all [Accessed 26 March 2021] .

Ahmed, S. (2004). The Politics of Emotions. Edinburgh: University of Edinburgh Press.

Al-Rawi, A. (2017). Viral News on Social Media. Digital Journalism 7 (1), pp. 63-79.

Berlant, L. (1991). The Anatomy of National Fantasy: Hawthorne, Utopia, and Everyday Life. Chicago: Chicago University Press.

Bertelsen, L. \& Murphie, A. (2010). An Ethics of Everyday Infinites and Powers: Félix Guattari and the Refrain. In: M. Gregg and G. Seigworth, eds., The Affect Theory Reader. Durham: Duke University Press, pp.138-157.

Brown, W. (2006). Regulating Aversion: Tolerance in the Age of Identity and Empire. Princeton: Princeton University Press.

B.T. (2017). Kasper forstår ikke \#MeToo-bølgen: 'Skeptiske Idioter som mig bliver jo ikke klogere.' Facebook status update. [Accessed 21 March 2021].

B.T. (2018). Sussi la Cour efter \#metoo: 'Hvor er kvindernes selvrespekt i forhold til at sige nej?' Facebook status update. [Accessed 21 March 2021]. CBS (2017). More Than 12 Million Facebook \#MeToo Facebook-Posts, Comments, Reactions in 24 Hours. [online] CBS https://www.cbsnews. com/news/metoo-more-than-12-million-facebook-posts-comments-reactions-24-hours/ [Accessed 21 March 2021].

Chouliaraki, L. (2013). The Ironic Spectator: Solidarity in the Age of Post-Humanitarianism. Oxford: Polity Press.

Clarke, A. (2005). Situational Analysis: Grounded Theory After the Postmodern Turn. Thousand Oaks, CA and London: Sage Publications.

Constantiou, I. \& Kallinikos, J. (2014). New Games, New Rules: Big Data and the Changing Context of Strategy. Journal of Information Technology 30(1).pp.44-57. 
Dean, J. (2014) Communicative Capitalism and Class Struggle. Spheres: Journal for Digital Culture 1, pp.1-16.

De Souza e Silva, A. \& Frith, J. (2012). Mobile Interfaces in Public Space: Locational Privacy, Control, and Urban Sociability. Oxford: Routledge.

Deleuze, G. (1994). Difference and Repetition. New York: Columbia University Press.

Deleuze, G. \& Guattari, F. (1987). A Thousand Plateaus: Capitalism and Schizophrenia. London and New York: Continuum.

DR (2017). Præst Sørine Gotfredsen mener, at \#at \#matoo er dybt problematisk og skaber en trættende offermentalitet. Er du enig? Facebook status update. [Accessed 21 March 2021].

DR (2017a). \#MeToo fortsætter i Danmark: 132 sangerinder i opråb mod overgreb og sexchikane. Facebook status update. [Accessed 21 March 2021]. DR (2017b). Vi må tale om en bagatelgrænse, siger Hans Bonde om krænkelseskulturen i forbindelse med \#Metoo. Har han en pointe? Facebook status update. [Accessed 21 March 2021].

DR (2018). Den svenske presse har i ti tilfælde ikke fulgt god presseskik i deres dækning af \#metoo-sager, lyder det fra det svenske pressenævn. Giver du dem ret?. [Accessed 21 March 2021].

Entman R. M. (1993). Framing: Toward Clarification of a Fractured Paradigm, Journal of Communication 43 (4), pp. 51-58.

Freeley, K. (2012), Gossip and News: On Modern U.S. Celebrity Culture and Journalism. History Compass 10 (6), pp. 467-482.

Fritsch, J., Kofoed, J., \& Reestorff, C. M. (2020). Strategic Cyberbullying and the Reorganisation of Political Culture: Interfacial Refrains, Affective Circulation and @RealDonaldTrump.Conjunctions: Transdisciplinary Journal of Cultural Participation 7 (1), pp. 1-21.

Gibbs, M., Meese, J., Arnold, M., Nansen, N. \& Carter, M. (2015). \#Funeral and Instagram: Death, Social Media, and Platform Vernacular. Information, Communication \& Society 18 (3), pp. 255- 268.

Grusin, R. (2010). Premediation: Affect and Mediality After 9/11. New York: Palgrave Macmillan.

Hansen, L., Arvidsson, A., Nielsen, F. A., Colleoni, E. \& Etter, M. (2011). Good Friends, Bad News Affect and Virality in Twitter. In: J. J. Park, L. T. Yang, C. Lee, eds., Future Information Technology. Communications in Computer and Information Science 185. Berlin: Springer, pp. 34-43. 
Hermida, A., Fletcher, F., Korell, D. \& Logan, D. (2012). Share, Like, Recommend: Decoding the Social Media News Consumer. Journalism Studies 13(5-6), pp. 815-824.

Hjarvard, S. (2015). Framing: Introduktion til et Begreb og en Klassisk Tekst. MedieKultur: Journal of Media and Communication Research 31 (58), pp. 104-114.

Jarvey, N. (2017). "Sexual Assault Movement \#MeToo Reaches Nearly 500,000 Tweets. [online] Hollywood Reporter. Available at: https:// www.hollywoodreporter.com/news/metoo-sexual-assault-movement-reaches-500000-tweets-1049235 [Accessed 26 March 2021].

Jenkins, H., Ford, S. \& Green, J. (2013). Spreadable Media: Creating Value and Meaning in a Networked Culture. New York: New York University Press. Jyllands-Posten (2017). JP mener: \#metoo-bevægelsen ender i \#youtoo og fri adgang til at hænge folk ud. Facebook status update. [Accessed 21 March 2021].

Jyllands-Posten (2017b). Bertel Haarder blander sig i \#metoo-debatten som en gammel 68'er. 'Det er ærgerligt, hvis vi ender med at blive lige så sexfikserede og kropsforskrækkede som f.eks. nogle muslimske miljøer er' Facebook status update. [Accessed 21st March 2021].

Jyllands-Posten (2018). 'MeToo forekommer at være nået til det punkt, hvor bevægelsen enten radikaliseres til en udfoldet kønskrig eller lægger sig til at d $\emptyset^{\prime}$ mener historiker Henrik Jensen.Hvad mener duer det på tide at lægge MeToo-bevægelsen i graven? Facebook status update. [Accessed 21st March 2021].

Kofoed, J. (2013). Affektive Rytmer: Spekularitet og Ubestemmelighed i Digital Mobning. In: J. Kofoed, D. M. Søndergaard, eds., Mobning Gentcenkt. Copenhagen: Hans Reitzel Forlag, pp. 161-193.

Madsen, J. J. (2008). Politiken afviser tabloid - foreløbig... [online] Journalisten. Available at: https://journalisten.dk/politiken-afviser-tabloid-forelobig/ [Accessed 26 March 2021].

Mahdavi, P. (2018). How \#MeToo Became a Global Movement. [online] Foreign Affairs. Available at: https://www.foreignaffairs.com/articles/2018-03-06/how-metoo-became-global-movement [Accessed 27 March 2021].

Martin, F. \& Dwyer, T. (2019). Sharing News Online: Commendary Cultures and Social Media News Ecologies. Cambridge: Palgrave Macmillan.

Massumi, B. (2002). Parables for the Virtual: Movement, Affect, Sensation. Durham: Duke University Press. 
Massumi, B. (2009). Micropolitics: Exploring Ethico-Aesthetics. Inflexions: A Journal for Research-Creation [online] 3, pp.1-20. Available at: http://www.senselab.ca/inflexions/volume_3/node_i3/massumi_ en_inflexions_volo3.html [Accessed 15 April 2011].

Mendes, K., Ringrose, J. \& Keller, J. (2019). Digital Feminist Activism. Oxford: Oxford University Press.

Milano, A. (2017). Suggested by a friend. If all the women who have been sexually harassed or assaulted wrote 'Me Too' as a status, we might give people a sense of the magnitude of the problem. Twitter post. [Accessed 21st March 2021].

Papacharissi, Z. (2015). Affective Publics: Sentiment, Technology, and Politics. Oxford: Oxford University Press.

Papacharissi, Z. (2016). Affective Publics and Structures of Storytelling: Sentiment, Events and Mediality. Information, Communication \& Society 19 (3), pp. 307-324.

Petersen, A. H. (2011). Towards an Industrial History of Celebrity Gossip: The National Enquirer, People Magazine and 'Personality Journalism' in the 1970s. Celebrity Studies 2 (2), pp. 131-149.

Politiken (2017). Ole Bornedal: Svært ikke at smile ad folk, der føler sig traumatiserede, 25 år efter de fik et klask i røven. Facebook status update. [Accessed 21 March 2021].

Politiken (2018). MeToo-mænd gør comeback: Er du klar til at tilgive Louis C.K., Kevin Spacey og James Franko. Facebook status update. [Accessed 21 March 2021].

Politiken (2018a). Den feministiske, venstrepopulistiske totalitarisme er ligesom de skovbrande, der har hærget landet hele sommeren. Facebook status update. [Accessed 21 March 2021].

Politiken (2018b). 'Længe har den ulmet, og MeToo har været gnisten, som har fået den til at blusse op og sprede sig med lynets hast,' skriver Marianne Stidsen i Dagens Kronik. Facebook status update. [Accessed 21 March 2021].

Rasmussen, S. (2020). Anarchival Scripts. Capacious: Journal for Emerging Affect Inquiry 2(1-2), pp.186-205. Available at: http://capaciousjournal.com/article/anarchival-scripts/ [Accessed 26 March 2021].

Reestorff, C. M. (2017). Culture War: Affective Cultural Politics, Tepid Nationalism and Art Activism. London and Chicago: Intellect Ltd. 
Reestorff, C. M. (2019). Lektor: Danske medier underminerer \#MeToo i jagten på hurtige klik. [online] Videnskab.dk. Available at: https:// videnskab.dk/kultur-samfund/danske-medier-underminerer-metoo-i-jagten-paa-hurtige-klik [Accessed 27 March 2021].

Sheller, M. (2015). News Now: Interface, Ambience, Flow, and the Disruptive Spatio-Temporalities of Mobile News Media. Journalism Studies 16 (1), pp. 12-26.

Slots-og kulturstyrelsen (2017). Mediernes udvikling i Danmark: Globaliseringen af den danske mediebranche, Kulturministeriet [online]. Available at: https://mediernesudvikling.slks.dk/2017/ [Accessed 26 March 2021].

Slots-og kulturstyrelsen (2019). Mediernes udvikling i Danmark, Kulturministeriet [online]. Available at: https://mediernesudvikling.slks. dk/2019/ [Accessed 02 March 2021].

Stewart, K. (2007). Ordinary Affects. Durham: Duke University Press. Stieglitz., S. \& Dang-Xuan, L. (2013). Emotions and Information Diffusion in Social Media: Sentiment of Microblogs and Sharing Behavior. Journal of Management Information Systems 29 (4), pp. 217-248.

Thomsen, L. H. (2019). Inside the TV Newsroom: Profession Under Pressure. London and Chicago: Intellect Ltd.

TV2 (2017). Kendte danskere advares mod blodrus: er det sådan et samfund vi $\emptyset$ nsker? Facebook status update. [Accessed 21 March 2021].

Wahl-Jorgensen, K. (2018). Emotions, Media, and Politics. Cambridge: Polity Press.

Wånggren, L. (2016). Our Stories Matter: Storytelling and Social Justice in the Hollaback! Movement. Gender and Education 28 (3), pp. 401-415.

Warfield, K. (2016). Making the Cut: An Agential Realist Examination of Selfies and Touch. Social Media + Society 1(4), pp.1-10.

Warner, M. (2007). Publics and Counterpublics. New York: Zone Books. Welbers, K. \& Opgenhaffen, M. (2018). Presenting News on Social Media. Digital Journalism 7 (1), pp. 45-62.

Witschge, T., Anderson, C. W., Domingo, D., \& Hermida, A. (2016). The Sage Handbook of Digital Journalism. London: Sage Reference.

Zuboff, S. (2015). Big Other: Surveillance Capitalism and the Prospects of an Information Civilization. Journal of Information Technology 30 (1), pp. 75-89.

Zuboff, S. (2019). Surveillance Capitalism and the Challenge of Collective Action. New Labor Forum 28 (1), pp. 10-29. 